\title{
Nursing Education and Emotional Intelligence and Empathetic Tendency: A Cross-Sectional Study
}

\author{
Y1lmaz DAG ${ }^{1}$ Hafize OZTURK CAN ${ }^{2}$ \\ 1. Md. Suat Seren Hospital of Chest Diseases Izmir TURKEY \\ 2. Ege University Faculty of Health Sciences Bornova/ Izmir TURKEY
}

\begin{abstract}
This study was carried out to determine the effects of nursing education on the development of emotional intelligence and empathetic tendency in nursing students. Methods: The study was designed as a cross-sectional one, and the study population comprised 152 nursing students, The Emotional Intelligence Assessment and the Empathetic Tendency Scale were used as data collection tools. Data collected was analyzed using Statistical Package for Social Sciences (SPSS).Results: Of the students, $82.9 \%$ were female. The means of Emotional Intelligence Assessment (141.7 \pm 22.9$)$ and Empathetic Tendency Scores (68.5 \pm 8.1$)$ were found as respectively. Conclusion: No statistically significant differences were observed between Emotional Intelligence Scores of the students by their year at school. However, a statistically significant difference was found between the students' mean Empathetic Tendency Scores in terms of their year at school.
\end{abstract}

Keywords: Nursing, nursing education, emotional intelligence, empathetic tendency

DOI: $10.7176 / \mathrm{JHMN} / 70-04$

Publication date: January $31^{\text {st }} 2020$

\section{INTRODUCTION}

The term Emotional intelligence (EI) was first used in 1990 by psychologist Peter Salovey (Mayer, Salovey, 1990). Dr. Daniel Goleman (1995) defined EI as "self-motivation, being able to continue despite setbacks, the ability to postpone satisfaction by controlling impulses, mood regulation, empathizing, cherishing the hope, not allowing problems to prevent one from thinking" (Goleman, 2013). EI have constructed a model with five dimensions of ability. These are: self-awareness, emotional self-regulation, motivation, empathy, and social skills. These contribute to development of one's self-confidence and self-confidence has an important role in one's self-actualization (Goleman, 2013; Stys, Brown, 2004: Por et al. 2011; Benson et al. 2010).

The empathetic tendency (ET), one of the components of EI, which describes someone's potential to develop empathy, can be defined as an ability to understand the feelings of an individual asking for advise and to get influenced by his emotional experiences and the desire to help (Williams, Stickley, 2010). Individuals with higher ET show helping behavior more often (Dökmen, 2004).

EI and empathy are important communication skills enabling professionals working in areas related to human health to provide successful and effective services. Studies of these skills have indicated that they strengthen the positive interaction between individuals, and enable service providers to derive satisfaction from their personal and professional life (Ioannidou, Konstantikaki, 2008; McQueen 2004; Zeidner et al. 2004). EI and empathy are complex, multi-dimensional, learnable, teachable, interacting, powerful communication tools with moral, cognitive, emotional, and behavioral components (Ioannidou, Konstantikaki 2008; Tutuk et al. 2002; Ward et al. 2012). It is assumed that EI enhances ET, that ET enhances empathic skills and that the nurse would give the patient a better quality of care with the development of skills and sensitivity. Therefore, in the nurse education literature, there has recently become a growing trend to associate empathy with EI (Evans, Allen, 2002; Freshwater, Stickley, 2004; McQueen, 2004; Hurley, 2008, Williams, Stickley, 2010).

It is extremely important for nurses and nursing students, since they are professionals most sensitive to human needs, to develop EI levels (McQueen, 2004). It is argued that student nurses' EI capabilities should be assessed and their interpersonal skills should be developed during their education before they start their professional life (Cadman, Brewer, 2001; McQueen 2004). Assessment of student nurses' EI levels and determination of their requirements related to this issue play an important role in the development of training programs aiming to promote emotional intelligence (Sevindik et al. 2012).

With this research, it was intended to evaluate the impact of nursing education on the development of the EI and ET of students majoring in nursing in universities in Turkey.

\subsection{Background / Literature}

Nursing education at the university level in Turkey began in 1955. Higher education of nursing in Turkey, as well as the other trainings at the graduate level, is given for four years after a total twelve years of primary, secondary and high school education. Today, nurses can obtain a master's (MSc started in 1968) and doctoral degree ( $\mathrm{PhD}$ started in 1972). Nursing Education Programs are carried out in accordance with the European Union norms and Alma Ata declaration (Dal, Kitis, 2008; Bahcecik, Alpar, 2009). Professional nursing 
education is based on cultural and professional knowledge, clinical and conceptual skills and the individual's value system. During this training process, students receive theoretical knowledge, build clinical judgment in the application areas and try to put their theoretical knowledge into practice. Nursing education deals not only with care provided for an individual, family and community, but also with health promotion and health education (Avsar, Kasıkc1, 2010).

Student nurses should gain these skills which contribute to the development of knowledge to be used for the establishment of relationship between the patient and nurse based on the provision of healthcare, constitute an important dimension of nursing art and complete each other during their basic education and develop them through practices. In studies conducted on the issue, it has been noted that student nurses have low or moderate levels of EI (Avsar, Kasıkc1 2010; Kuzu, Eker 2010; Sevindik et al. 2012; Y1lmaz, Ozkan 2011) and empathy skills (Akınc1, Akgün 2011; Arifoğlu, Razı 2011; Nunes et al. 2011), which should be taken into account when a curriculum is prepared. Development of students' EI and empathy skills which will determine the effectiveness of interpersonal skills and the nature of the behavior they display while they provide care will help them to become successful members of the profession (Ioannidou, Konstantikaki 2008). Therefore, the effects of knowledge and skills student nurses acquire during their education on the development of their EI and empathy skills should be determined, and education programs which will support and develop these skills of cognitive and affective domains of nursing must be configured.

Themes in this literature align within the following three areas: EI and the nature of nursing, nursing education, nursing leadership. These themes are: students need to understand the emotional nature of nursing to be prepared for practice, to deliver competent nursing care; and to effectively deal with chaotic working environments (Smith et al. 2009). Recognition of the importance of EI in relationships and in work performance seems to be an important starting point. Approaches can be incorporated into educational program to foster these skills, in particular self-awareness, self-regulation and social skills (McQueen, 2004).

According to experts, the level of EI is not determined hereditarily; in addition it does not develop during early childhood. As a general opinion, contrary to IQ that does not demonstrate much development between 1319 years of age, the possibility to learn EI is considerably high and it may reach to a more efficient level by constantly developing life long (Goleman, 2013). The view that EI is based on learned habits leads experts to focus on the importance and role of education in the development of capacities in this area. The function of education is to help a person use the intelligence profile unique to him/her to master in fields and tasks which will ensure his/her development in the community. The development of EI is intertwined with development processes such as cognitive maturation and biological maturation. In addition, EI skills can be developed and strengthened through education and are of importance at all levels of education. (Yesilyaprak 2001; Cadman, Brewer, 2001)

This research was carried out to determine the effects of nursing education on the development of emotional intelligence and empathetic tendency in students.

\section{METHODS}

This research is a cross-sectional type of study carried out to determine the influence of nursing education on the development of EI and ET in students. The research questions are as follows:

"Does nursing education have any influence on the development of EI and ET in students?"

The hypotheses of the study are as follows:

- Nursing education affects the development of students' EI.

- Nursing education affects the development of students' empathic tendencies.

2.1. Study Population and Sample Selection: The population of the study comprised 382 students. Of the students, $72.4 \%$ were in the 18-22 age-group and $82.9 \%$ were female. When the students were asked where their longest place of residence was, fifty percent of the students' longest place of residence was a province/big city.

2.2. The sample of the research: The first and fourth graders comprised the sample of the research. The number of the first and fourth grade students in School of Health, Nursing Department is 170. No sample selection method was used so all the first and fourth grade students constituted the sample of the research. Of the students, 152 who accepted to participate in the research were enrolled in the study and attended courses during the survey data were collected. Of the participating students in the research, $61.2 \%$ were first graders and $38.8 \%$ were fourth graders. This study was conducted with nursing students of School of Health in the spring semester in Izmir/ Turkey

\subsection{Instrument}

The data of the research were collected with the following: Form related to students' socio-demographic 
characteristics, Emotional Intelligence Evaluation Scale and Empathetic Tendency Scale.

2.3.1. Form related to Socio-demographic Characteristics; the form related to socio-demographic characteristics, developed by the researcher, was comprised of 12 questions and was used to determine students' socio-demographic characteristics.

2.3.2. Emotional Intelligence Evaluation Scale; the Turkish validity and reliability study of The Emotional Intelligence Evaluation Scale (EIES), which was originally developed by Hall (1999), was carried out by Ergin (2000), and was used in studies performed in Turkey (Avsar, Kasıkc1 2010; Kuzu, Eker 2010; Unsar et al. 2008). The Cronbach alpha values of the EIES are given in Table 1. The scale is comprised of five subscales; Emotional Awareness, Managing One's own Emotions, self-motivation, empathy and social skills. The 30-item scale is a 6-point Likert-type scale. The items are rated as follows: $1=$ completely disagree, and $6=$ completely agree. The total scores obtained from each of the 30 items give the total scores of emotional intelligence (Ergin 2000).

Table 1. Cronbach Alpha Values of the EIES according to studies carried out

\begin{tabular}{|c|c|c|c|}
\hline & Ergin (2000) & Unsar et al. (2009) & This study \\
\hline Cronbach Alpha Values & 0.84 & 0.87 & 0.94 \\
\hline
\end{tabular}

2.3.3. Empathetic Tendency Scale (ETS); ETS was developed by Dökmen (1988) to measure individuals' empathy potential in daily life. The Cronbach alpha values of the ETS are given in Table 2. It is a Likert type of scale comprised of 20 questions and each question is scored from 1 to 5 . The possible minimum score to be obtained from the scale is 20 and the possible maximum score is 100 . The total score defines the ET of the participants. While high scores indicate that empathetic tendency is high, low scores indicate that ET is low (Dökmen 1998; Mete, Gercek 2005).

Table 2. Cronbach Alpha values according to studies carried out by using ETS

\begin{tabular}{|l|c|c|c|c|}
\hline & $\begin{array}{c}\text { Dökmen } \\
(\mathbf{1 9 9 8 )}\end{array}$ & $\begin{array}{c}\text { Mete \&Gercek } \\
\mathbf{( 2 0 0 5 )}\end{array}$ & $\begin{array}{c}\text { Kocak \&Önen } \\
\text { (2013) }\end{array}$ & This Study \\
\hline Cronbach Alpha Values & 0.72 & 0.82 & 0.82 & 0.68 \\
\hline
\end{tabular}

\subsection{Data Analysis}

Ordinal variables were evaluated by arithmetic mean and standard deviation, and minimum and maximum values, whilst nominal variables were evaluated by frequency and percentages. The Sample t test was used to determine the difference between variables. In all the tests, 0.05 was considered as the significance level. The dependent variables in research are the mean scores of EI Assessment and Subscale and the mean scores of ETS; and independent variables are age and grade of students.

2.5. Ethical Considerations: School of Health Administration's written permission was obtained for data collection. The principles of willingness and voluntariness were emphasized for participation in the study, and students' verbal consents/approvals were received. They were instructed not to write their names on the data collection forms

\section{FINDINGS}

The research aimed to determine the effects of nursing education on the development of EI and ET in students and 152 nursing students comprised its sample. The findings of the research include students' EI and ET scores.

Table 3. The distribution of the students according to the type of trainning they receive and training on self-development

\begin{tabular}{|l|c|c|}
\hline Trainning status & Number & \% \\
\hline yes & 66 & 43.4 \\
\hline No & 86 & $\mathbf{1 0 0 . 0}$ \\
\hline TOTAL & $\mathbf{1 5 2}$ & 22.4 \\
\hline The type of Trainning * & 42 & 20.3 \\
\hline Communication & 38 & 17.0 \\
\hline Coping with stress & 32 & 14.9 \\
\hline Motivation & 28 & 10.6 \\
\hline Empaty & 20 & 5.8 \\
\hline Self-recognition & 11 & 5.3 \\
\hline Assertiveness assertiveness & 10 & 3.7 \\
\hline Emotional intelligence & 7 & $\mathbf{1 0 0 . 0}$ \\
\hline Conflict method & $\mathbf{1 8 8}$ & \\
\hline TOTAL & & \\
\hline More & & \\
\hline
\end{tabular}

* More than one topic is specified. 
Table 3 shows the distribution of the students according to the type of training they receive and training on self-development. It was found that $43.4 \%$ of the students received training. It was determined that they received the highest level of training in communication and coping with stress.

Students' EIES and subscale scores and their mean scores of ETS and the scale's scoring for assessment are shown in Table 4. According to this, the mean scores were as follows: $141.7 \pm 22.9$ for the whole EIES. These results indicate that EI scores were within the normal limits. In addition, the mean total ETS score the students participating in the research achieved was $68.5 \pm 8.1$.

Table 4. The distribution of the mean scores of EIES and ETS

\begin{tabular}{|l|c|c|c|c|c|}
\hline & \multicolumn{2}{|c|}{ Sample Scores } & \multicolumn{3}{c|}{ Assessment of EIES } \\
\hline EIES and Subscales & X-SD & Min-Max & Low & Normal & High \\
\hline Emotional Awareness & $28.5 \pm 5.3$ & $8.0-36.0$ & 25 and below & $26-30$ & 31 and above \\
\hline Managing One's own Emotions & $28.7 \pm 5.4$ & $9.0-36.0$ & 26 and below & $27-31$ & 32 and above \\
\hline Self-motivation & $27.4 \pm 4.6$ & $10.0-36.0$ & 26 and below & $27-30$ & 31 and above \\
\hline Empathy & $28.4 \pm 5.1$ & $11.0-36.0$ & 25 and below & $26-30$ & 31 and above \\
\hline Social skills & $28.4 \pm 4.7$ & $8.0-36.0$ & 24 and below & $25-29$ & 30 and above \\
\hline Total Mean Scores of EIES & $\mathbf{1 4 1 . 7} \pm \mathbf{2 2 . 9}$ & $\mathbf{4 8 . 0 - 1 8 0 . 0}$ & $\mathbf{1 2 9}$ and below & $\mathbf{1 3 0 - 1 5 4}$ & $\mathbf{1 5 5}$ and above \\
\hline Mean Score of ETS & $\mathbf{6 8 . 5} \pm \mathbf{8 . 1}$ & $\mathbf{4 4 . 0 - 9 0 . 0}$ & & & \\
\hline
\end{tabular}

Table 5 shows the comparison of EIES and ETS in terms of age groups, grade and training in improving themselves. Comparison of age groups and raining in improving themselves revealed statistically significant difference between the total EIES score and the subscale scores $(p>0.05)$. In addition, no statistically significant relationship was detected between the students' age groups and their ETS scores. When the relationship between the students' mean EIES and subscale scores and their ET was compared in terms of their grade at school, no statistically significant difference was found between their total EIES score and subscale scores $(p>0.05)$. However, a statistically significant relationship was detected between the students' grade at school and mean ETS scores $(\mathrm{p}<0.05)$ (Table 5).

Table 5. Comparing the students' total mean scores of EIES and ETS

\begin{tabular}{|c|c|c|c|c|c|c|c|c|}
\hline & & \multicolumn{6}{|c|}{ EIES and Subscale Scores } & \multirow[b]{2}{*}{ ETS } \\
\hline & & $\begin{array}{l}\text { Emotional } \\
\text { Awareness }\end{array}$ & $\begin{array}{l}\text { Managing } \\
\text { One's own } \\
\text { Emotions }\end{array}$ & $\begin{array}{c}\text { Self- } \\
\text { Motivation }\end{array}$ & Empathy & $\begin{array}{l}\text { Social } \\
\text { Skills }\end{array}$ & EIES Total & \\
\hline & $\mathrm{n}$ & $\mathrm{X}-\mathrm{SD}$ & $\mathrm{X}-\mathrm{SD}$ & $\mathrm{X}-\mathrm{SD}$ & $\mathrm{X}-\mathrm{SD}$ & $\mathrm{X}-\mathrm{SD}$ & $\mathrm{X}-\mathrm{SD}$ & $\mathrm{X}-\mathrm{SD}$ \\
\hline \multicolumn{9}{|c|}{ Age Groups } \\
\hline $\begin{array}{l}18-22 \\
\text { age- } \\
\text { group }\end{array}$ & 110 & $28.3 \pm 5.1$ & $28.5 \pm 5.4$ & $28.5 \pm 5.4$ & $28.2 \pm 4.9$ & $28.4 \pm 4.4$ & $141.0 \pm 21.7$ & $67.9 \pm 8.2$ \\
\hline $\begin{array}{l}23 \text { and } \\
\text { above }\end{array}$ & 42 & $29.2 . \pm 5.8$ & $29.4 \pm 5.5$ & $27.7 \pm 5.2$ & $28.9 \pm 5.6$ & $28.4 \pm 5.6$ & $143.7 \pm 26.2$ & $70.1 \pm 7.7$ \\
\hline $\mathrm{p}^{*}$ & & .360 & .397 & .718 & .513 & .947 & .517 & .139 \\
\hline \multicolumn{9}{|l|}{ Grade } \\
\hline $\begin{array}{l}\text { First } \\
\text { grade }\end{array}$ & 93 & $28.0 \pm 5.4$ & $28.3 \pm 5.4$ & $27.2 \pm 4.5$ & $27.8 \pm 5.1$ & $28.0 \pm 4.5$ & $139.5 \pm 22.4$ & $67.4 \pm 8.1$ \\
\hline $\begin{array}{l}\text { Fourth } \\
\text { grade }\end{array}$ & 59 & $29.4 \pm 5.1$ & $29.4 \pm 5.3$ & $27.8 \pm 4.8$ & $29.4 \pm 4.9$ & $28.9 \pm 5.0$ & $145.1 \pm 23.6$ & $70.4 \pm 7.9$ \\
\hline $\mathrm{p}^{*}$ & & .125 & .247 & .392 & .057 & .262 & .143 & .030 \\
\hline \multicolumn{9}{|c|}{ Training in improving themselves } \\
\hline Yes & 66 & $28.59 \pm 5.55$ & $28.74 \pm 5.63$ & $27.90 \pm 5.00$ & $28.71 \pm 5.31$ & $28.48 \pm 5.21$ & $142 . \pm 43$ & $69.48 \pm 8.59$ \\
\hline No & 86 & $28.54 \pm 5.27$ & $28.83 \pm 5.34$ & $27.17 \pm 4.32$ & $28.26 \pm 5.04$ & $28.39 \pm 4.46$ & $141.22 \pm 21.84$ & $67.91 \pm 7.84$ \\
\hline $\mathbf{p}$ & & .960 & .916 & .334 & .600 & .909 & .747 & .244 \\
\hline
\end{tabular}

*The Sample t test. In all the tests 0.05 was considered as the significance level.

\section{DISCUSSION}

The effects of nursing education on the development of the students' Emotional Intelligence (EI) and ET were assessed using EIES and ETS. There are a lot of instruments used to assess and measure EI (Deniz et al. 2013; MTD Trainning \&Ventus Publishing ApS, 2010; Yesilyaprak, 2001). In this present study, the students' mean EI score (141.7 \pm 22.9$)$ obtained from the EIES was considered moderate. In the literature, studies conducted on nursing students' reported that their EI total score was at a moderate level (Avsar, Kasıkc1 2010; Kuzu, Eker, 2010; Unsar et al. 2009; Por et al. 2011; Y1lmaz, Ozkan, 2011). Another study, they determined that the mean 
total score of the students was $123.31 \pm 34.27 .40 \%$ of students stated that their emotional intelligence needs to be improved (Fırat Kılıç et al. 2017). These results are consistent with the results of this present study. Nursing students are expected to have higher EI since nursing education is considered to be human and social lifeoriented. It is reported in the pertinent literature that factors such as family and environment, values and spirituality affect the development of emotional intelligence. Educational environment, intra-curricular activities, guidance and trainers are also said to be effective in the development of EI (Birol et al. 2009; McQueen, 2004; Smith et al. 2009; Yesilyaprak, 2001). Besides these; age, family environment and gender are reported to be effective (Tugrul, 1999). Statistical analysis conducted in this present study revealed no significant relationship between the mean total EIES and subscale scores and grades at school. These findings do not support the hypothesis "Nursing education affects the development of students' EI" statistically. Similar results were found in the study of Firat et al (2017). In other studies, statistically significant relationships were reported between the EI and subscale scores and years at school (Benson et al. 2010; Unsar et al. 2009). However, it was identified that fourth graders had higher mean EI and subscale scores than did first graders. In other studies carried out on the effect of education on emotional intelligence of nursing students, it was stated that students had high mean scores of EI (Avsar, Kasıkc1, 2010; Kuzu, Eker 2008; Unsar et al. 2009; Y1lmaz, Ozkan, 2011). In several other studies, the highest EI scores, although statistically not significant, were achieved by the fourth-grade students, which suggests that nursing education contributed to the enhancement of the emotional intelligence level of the students. The increase in EI scores is believed to stem from the fact that the nursing education curriculum in Turkey includes such topics as problem solving, stress management, conflict resolution etc. in courses like Nursing Education and Management and Psychiatric Nursing.

Several factors such as theoretical courses/practices, student-teacher relationships, student-student relationships etc. may have contributed to increases in the students' emotional intelligence as their years at school increased (Avsar, Kasıkc1, 2010; Benson et al. 2010). All these factors enable students to gain skills of self-awareness, and understanding and managing their emotions. It is thought that this difference may have stemmed from such factors as the place of residence and differences between educational opportunities.

The Bar on Emotional Quotient Inventory: In a cross-sectional study performed using the Short (EQ-i:S), the difference between the total EQ scores the students obtained in their $1^{\text {st }}$ and $4^{\text {th }}$ years was statistically significant, with their scores in the $4^{\text {th }}$ year being higher. There were also statistically significant differences the difference between years in terms of their total EI scores was statistically significant. There were also statistically significant differences between the $1^{\text {st }}$ and $4^{\text {th }}$-year students' scores in terms of the scores they obtained from the interpersonal and stress management subscales, with the $4^{\text {th }}$-year students' scores being higher (Benson et al.2010). In another study, in which the same scale was used, no statistically significant difference was reported between the mean EI scores in terms of the students' years at school (Y1lmaz, Ozkan, 2011) and conducted only with the $1^{\text {st }}$-grade students, the mean EI score was found as $116.0 \pm 19.7$ (Duman, Acaroglu, 2014; Sevindik et al. 2012).

In this research, no statistical relationship was found between the students' ages and their EIES and subscale scores. However, it was determined that as the students' ages increased so did their EIES total, "Emotional Awareness", "Managing One's own Emotions" and "Empathy" scores. It was also observed that while the mean "Self-motivation" subscale scores decreased in the students 23 years old or over, their mean "Social Skills" subscale scores remained unchanged.

When EI was examined according to the age groups, it was observed that there was a positive relationship between EI and age, and that as the age increased so did the EI scores (Por et al. 2011). In a study carried out by Kuzu and Eker (2008) on nursing students, EI scores were found higher in students 23 years old and above. EI was found to be the predictor of life satisfaction, healthy psychological adaptation, positive interactions with peers and family, and higher parental warmth (Stys, Brown, 2004). The mean scores of EI according to age groups demonstrated similar results in other studies (Y1lmaz, Ozkan, 2011). Literature reviews suggest that EI development begins during childhood and progresses with age (Deniz et al. 2013; Tugrul 1999). In the literature, although there are some studies indicating that EI increases with age (Kuzu, Eker, 2008; Por et al. 2011), many studies report no significant relationship between EI and age (Harrod, Scheer, 2005; Unsar et al. 2009). In the literature, it is indicated that EI neither changes nor improves with age, that it improves in line with the person's desire and efforts, and that the environment has positive effects on its development. It is stated that EI improves with experience, the person's being willing to improve himself/herself, education he/she has received on EI, information he/she has obtained from the pertinent literature and how he/she puts this information into practice (Smith et al. 2009; Y1lmaz, Ozkan, 2011).

The second hypothesis of this study is that "Nursing education affects the development of students' empathic tendencies." According to the study results, the mean ETS score (68.5 \pm 8.1$)$ and the mean "Empathy" subscale score of the EIES $(28.4 \pm 5.1)$ were at a moderate level. ET is generally a personal characteristic, it can be developed through education, and nursing students are expected to develop this characteristic during education (Hodges, 1991). In the study all the students had moderate ETS scores. Tutuk et al. (2002), Mete, 
Gercek (2005), Sabanc1ogulları et al. (2007), Akıncı and Akgün (2011) obtained similar results in nursing students. In a study conducted on nursing freshmen in the Turkish Republic of Northern Cyprus" the mean ET score determined by Arifoğlu and Razı (2011) was higher than the results of this present research. This finding demonstrates that students who took a separate test to enter nursing school in the Turkish Republic of Northern Cyprus chose the nursing profession willingly. The level of clinical exposure and number of clinical placements in areas of nursing where the nurse-patient relationship plays a significant part in care, such as mental health, could impact the level of a nurse's skill (Brunero et al. 2010; Cinar et al. 2007).

When we examined mean scores of ETS in terms of year at school, we found higher scores in the fourth graders than in the first graders. We also found statistically significant difference in the analysis performed according to years at school $(\mathrm{p}<0.05)$. This result supports the second hypothesis of the research. It may be interpreted that courses such as interpersonal relations, psychiatry and psychology taken by fourth graders and students interacting with patients or healthy individuals during applied training may lead to the development of ET in students. In other studies carried out on the effect of education on ET of nursing students, similar results were achieved (Akınc1, Akgün 2011; Cinar et al. 2007; Karaca et al. 2013; Mete, Gercek 2005; Sabanc1ogulları et al.2007; Tutuk et al. 2002). These results are consistent with the results of this present research.

According to age groups, the mean scores of ETS were not found statistically significant ( $\mathrm{p}>0.05)$. However, the students 23 years old and above had higher mean scores. Arifoğlu and Razı (2011) obtained similar findings in their study. Also, in another study it was stated that factors such as individual's social responsiveness level, assistance behavior and education had an effect on the development of empathetic tendency (Dökmen 2004).

ET constitutes the emotional dimension of empathy and is an innate personality trait. ET necessitates attitudinal development and personality changes rather than cognitive development or a skill. Therefore, it is very hard for someone to change his/her ET. To do so, he/she needs to have a longer education (Mete, Gercek, 2005). The importance of EI in nursing, which is considered the foundation of success in personal and professional life, and its contribution to nursing should be emphasized to both educators and students through various programs. In order that student nurses should be successful in their professional lives, their capabilities in problem solving, critical thinking analyzing and criticizing should be improved. However, EI should be learned and developed not only during nursing education but lifelong (Cadman, Brewer, 2001; McQueen, 2004).

\section{CONCLUSION AND RECOMMENDATIONS}

It was determined that although the fourth graders' mean EI scores were higher than were those of first graders, the difference was not significant", so nursing education did not cause any changes in emotional intelligence of the students. Besides, it was detected that the students' mean ETS scores

were at a moderate degree and higher in fourth graders and there were statistically significant differences between the students in terms of their years at school. This result demonstrated that nursing education has facilitated the development of ET in students.

\subsection{Recommendations}

- In order make contributions to the development of EI and ET in students, the curriculum of nursing education should be enriched and these practices must be arranged in such a way as to be extended over years.

- Education methods which will support the development of empathetic behaviors in students must be used in occupational courses and applications.

- The resources toward the development of EI and ET in students must be accessible.

Limitations: The results obtained from this study are applicable only to the student nurses surveyed and cannot be generalized. However, it may provide data and a point of view for future studies to be conducted on the subject. In addition, the literature review indicates that there are various scales used to assess EI and ET and studies investigating EI and ET. The results of this research were obtained using The Emotional Intelligence Evaluation Scale originally developed by Hall (1999) and ETS developed by Dökmen (1988).

\section{REFERENCES}

Akınc1, A., Akgün, G. (2011). Empathic Tendency and Empathic Skill of Nursing Students in Health College of Kirklareli University. Firat Journal of Firat Health Services (E-Journal) 6(17), 53-65.

Arifoğlu, B., Razı, GS. (2011). Management Course Academic Achievement Averages Of First Class Nursing Students. Dokuz Eylül University Hemşirelik Yüksekokulu Elektronik Dergisi. 4(1), 7-11., Available from: http://www.deuhyoedergi.org.

Avsar, G., Kasıkc1, M. (2010). Emotional Intelligence Levels of Students of Nursing College [Hemsirelik yüksekokulu ögrencilerinde duygusal zekâ düzeyi]. Anadolu Hemsirelik ve Saglik Bilimleri Dergisi [Journal of Anatolia Nursing and Health Sciences]. 13(1), 1-6. http://e- 
dergi.atauni.edu.tr/ataunihem/article/view/1025002746.

Bahcecik, N., Alpar, SE. (2009). Nursing Education in Turkey: From Past to Present. Nurse Education Today. 29(7), 698-703. doi:10.1016/j.nedt.2009.05.00.

Benson, G., Ploeg, J., Brown, B. (2010). A cross-sectional study of emotional intelligence in baccalaureate nursing students. Nurse Education Today. 30, 49-53. doi:10.1016/j.nedt.2009.06.006.

Birol, C., Atamturk, H., Silman, F., Sensoy, S. (2009). Analysis of The Emotional Intelligenge Level of Teachers Procedia Social and Behavioral Sciences 1(1), 2606-14. doi:10.1016/j.sbspro.2009.01.460.

Brunero, S., Lamont, S., Coates, M. (2010). A review of empathy education in nursing. Nursing Inquiry. 17(1), 65-74. do1: 10.1111/j.1440-1800.2009.00482.x.

Cadman, C., Brewer, J. (2001). Emotional Intelligence: A Vital Prerequisite for Recruitment in Nursing. Journal of Nursing Management. 9(6), 321- 4. do1: 10,1046 / j.0966-0429.2001.00261.x.

Cinar, N., Cevahir, R., Sahin, S., Sözeri, C., Kuguoglu, S. (2007). Evaluation of the Empathic Skills of Nursing Students with Respect to The Classes They are Attending. Revista Eletrônica de Enfermagem. 9(3), 588-95. Available from: http://www.fen.ufg.br/revista/v9/n3/v9n3a03.htm.

Dal, U., Kitis, Y. (2008). The Historical Development and Current Status of Nursing in Turkey. OJIN: The Online Journal of Issues in Nursing. 13 (2), do1: 10.3912/OJIN.Vol13No02PPT02;

Deniz, M.E., Ozer, E., Isık, E. (2013).Trait Emotional Intelligence Questionnaire-Short Form: Validity and Reliability Studies[Duygusal Zekâ Özelliği Ölçeği-Kısa Formu: Geçerlik ve Güvenirlik Çalışması]. Education and Science [Ĕgitim ve Bilim]. 38(169), 407-19.

Dökmen, U. (2004) . Contact Conflict and Empathy [İletişim Çatışmaları ve Empati]. 18th. Edit. Ankara, Sistem Print.

Dökmen, U., (1998). Arts and Communication Conflict and Empathy in Everyday Life [Sanatta ve Günlük Yaşamda Illetişim Çatışmaları ve Empati]. I.Edit. Ögünç Print, Istanbul.

Duman, D., Acaroglu, R. (2014). The Relationship Between Emotional Intelligence Levels and Empathy Skills of Nursing College's First Grade Students[Hemşirelik yüksekokulu birinci sınıf öğrencilerinin duygusal zekâ düzeyleri ile empati becerileri arasındaki ilişki]. Florence Nightingale Journal of Nursing [F.N. Hem. $\begin{array}{llll}\text { Dergisi]. } & 22(1), & 25-32 . & \text { ISSN }\end{array}$ http://www.journals.istanbul.edu.tr/iufnhy/article/view/5000013890.

Ergin, E.F. (2000). The Emotional Intelligence Level of University Students and 16 Research on The Relationship Between Personality Traits [Üniversite öğrencilerinin sahip oldukları duygusal zeka düzeyi ile 16 kişilik özelliği arasındaki ilişki üzerine bir araştırma], Selçuk University Institute of Social Sciences, Child Development and Education Department Master Thesis, Konya.

Evans, D., Allen, H. (2002). Emotional Intelligence: Its Role in Training. Nursing Times. 98 (27), 41-2.

Fırat Kılıç H, Çaglıyan S, Sucu Dag G. (2017). Emotional Intelligence Levels of Nursing Students and Affecting Factors [Hemsirelik Ögrencilerinin Duygusal Zeka Düzeyleri ve Etkileyen Faktörler]. Hemşirelikte Ë̆itim ve Araştırma Dergisi 2017;14 (4): 275-282. doi:10.5222/HEAD.2017.275

Freshwater, D., Stickley, T. (2004). The Heart of the Art: Emotional Intelligence in Nurse Education. Nursing Inquiry . 11(2), 91-8. do1: 10.1111/j.1440-1800.2004.00198.

Goleman, D. (2013). Emotional Intelligence (Why it can matter more than IQ)? Translate: Yüksel B.S., 30th Edit. Varlık Print, Istanbul. ISBN:9754341966

Harrod, N.R., Scheer, S.D. (2005). An exploration of Adolescent Emotional Intelligence in Relation to Demographic Characteristics. Adolescence. 40(159), 503-12.

Hodges, SA., (1991). An Experiment in The Development of Empathy in Student Nurses. Journal of Advanced Nursing. 16, 1296-300. do1: 10.1111/j.1365-2648.1991.tb01557.x

Ioannidou, F., Konstantikaki, V. (2008). Empathy and Emotional Intelligence:What is it Really about? International Journal of Caring-Sciences. 1(3), 118-23.

Karaca, A., Acıkgöz, F., Akkus, D. (2013). Is education and empathic skills and empathic tendencies?: Example of a Health Sciences. Acıbadem University Journal of Institute of Health Sciences [Acıbadem Üniversitesi Sağlık Bilimleri Dergisi]. 4(3),118-22.

Kocak, C., Önen, A.S., (2013). Emphatic Tendency Scale for Student Teachers: Validity and Reliability Studies, Educational Sciences: Theory \& Practice. 13(2), 958-64.

Kuzu, A., Eker, F. (2010). The Evaluation of Emotional Intelligence and Communication Skills of Nursing Students and The Other University Students in Comarative Way [Hemşirelik örgencilerinin duygusal zekâ ve iletişim becerilerinin diğer üniversite örgencileri ile karsılaştırmalı olarak değerlendirilmesi]. Journal of Nursing Research Development [Hemşirelikte Araştırma Geliştirme Dergisi] 12(3), 14-29. Avaible from: http://hemarge.org.tr/cknder/userles/les/2010/2010- vol12-sayi3-250.pdf.

Mayer, P., Salovey, J.D. (1990) . Emotional Intelligence. Imagination, Cognition and Personality 9(3), 185-211. DOI: 10.2190/DUGG-P24E-52WK-6CDG

McQueen, A.C.H. (2004). Emotional Intelligence in Nursing Work. Journal of Advanced Nursing. 47(1), 101-8. 
DOI: $10.1111 / \mathrm{j} .1365-2648.2004 .03069 . \mathrm{x}$

Mete, S., Gerçek, E. (2005). The Examination of Empathic Tendency and Skills on Nursıng Students who are Educated with PBL Method[PDÖ yöntemiyle eğitim gören hemşirelik öğrencilerinin empatik eğilim ve becerilerinin incelenmesi]. Cumhuriyet University Journal of Nursing High School [Cumhuriyet Üniversitesi Hemşirelik Yüksek Okulu Dergisi]. 9(2), 11-17..

MTD Trainning \&Ventus Publishing ApS. (2010). Emotional Intelligence, ISBN 978-87-7681-600-1

Nunes, P., Williams, S., SA, B., Stevenson, K. (2011). A Study of Empathy Decline in Students From Five Health Disciplines During Their First Year of Training. International Journal of Medical Education. 2, 12-7.

Por, J., Barribal, L., Fitzpatrick, J., Roberts, J. (2011). Emotional Intelligence: Its Relationship to Stress, Coping, Well-being and Professional Performance in Nursing Students. Nurse Education Today. 31(8), 855-60. doi:10.1016/j.nedt.2010.12.023

Sabanciogulları, S., Kelleci, M., Dogan, S., Gölbası, Z.(2007). The Empathic Tendency in Nursing Students Educated With Integrated Method According to The Years [Entegre Eğitim Programında Öğrenim Gören Hemşirelik Öğrencilerinin Empatik Eğilim Düzeylerinin Yıllara Göre İncelenmesi]. Cumhuriyet University Journal of Nursing High School [Cumhuriyet Üniversitesi Hemşirelik Yüksekokulu Dergisi] 11(2),1-6.

Sevindik, F., Uncu, F., Dag, D.G. (2012). The Investigation of Emotional Intelligence in Health School Students to Some Variables [Sağlık Yüksekokulu Öğrencielrinin Duygusal Zeka Düzeylerinin Bazı Değişkenler Açısından İncelenmesi] . Firat University Medical Journal of Health Sciences [FÜ Sağlık Bilimleri Tip Dergisi]. 26(1), 21-6. Avaible From: http://tip.fusabil.org/pdf/pdf_FUSABIL_836.pdf.

Smith, K.B., Profetto-McGrath, J., Cummings, G.G. (2009). Emotional Intelligence and Nursing: An Integrative Literature Review. International Journal of Nursing Studies. 46(12), 1624-36. DOI: http://dx.doi.org/10.1016/j.ijnurstu.2009.05.024

Stys, Y., Brown, S.L. (2004). A review of the emotional intelligence literature and implications for corrections. Research Branch Correctional Service of Canada.

Tugrul, C. (1999). Emotional Intelligence. Clinic Psychiatry. 1: 12-20.

Tutuk, A., Al, D., Dogan, S., (2002). Determining Communication Skills and Emphatic Levels of Nursing Students [Hemşirelik öğrencilerinin iletişim becerisi ve empati düzeylerinin belirlenmesi]. Cumhuriyet University Journal of Nursing High School [Cumhuriyet Üniversitesi Hemşirelik Yüksek Okulu Dergisi]. 6(2), 36-41..

Unsar, S., Findık U.Y, Sadırlı, S.K, Erol, O., Unsar, S. (2009). Emotional Intelligence Level of Edirne Health School Students. University and Community 9(1), 13-27. Avaible From: http://www.universitetoplum.org/text.php3?id=384.

Ward, J., Cody, J., Schaal, M., Hojat, M. (2012). The Empathy Enigma: An Empirical Study of Decline in Empathy Among Under Graduate Nursing Students. Journal of Professional Nursing. 28(1), 34-40. doi:10.1016/j.profnurs.2011.10.007

Williams, J., Stickley, T. (2010). Empathy and Nurse Education. Nurse Education Today. 30, $752-55$. doi:10.1016/j.nedt.2010.01.018

Yesilyaprak, B. (2001). Implications in Terms of Emotional Intelligence and Education. Journal of Theory and Practice of Educational Administration [Kuram ve Uygulamada Eğitim Yönetimi Dergisi]. 25, 139-46.

Y1lmaz, E., Özkan, S. (2011). The Emotional Intelligence Levels of Nursing Students According to Some Variables, Maltepe University Journal of Nursing Science and Art. 4(1), 39-52.

Zeidner, M., Matthews, G., Roberts, R. D. (2004). Emotional intelligence in Theworkplace: A Critical Review. Applied Psychology. 53(3), 371-99. DOI: 10.1111/j.1464-0597.2004.00176.x 